\title{
Liposomal Injection Dosage Form
}

National Cancer Institute

\section{Source}

National Cancer Institute. Liposomal Injection Dosage Form. NCI Thesaurus. Code C60931.

A substance composed of active and/or inert ingredient(s) encapsulated in liposomes and intended for injection. 